\title{
Effects of laser-assisted hatching and exposure time to vitrification solution on mouse embryo development
}

\author{
Hye Jin Kim', Sung Baek Park², Jung Bo Yang ${ }^{1}$, Young Bae Choi ${ }^{2}$, Ki Hwan Lee ${ }^{1}$ \\ 'Department of Obstetrics and Gynecology, Chungnam National University Hospital, Daejeon; ${ }^{2}$ Mirae i Infertility Clinic, Mirae Ladies Hospital, Daejeon, \\ Korea
}

Objective: This study was conducted to investigate the efficacy of laser-assisted hatching (LAH) and various vitrification times for embryonic development and blastocyst cell numbers.

Methods: First, 2-cell and 8-cell embryos were collected by flushing out the oviducts. In the control groups, they were vitrified for 8 or 10 minutes without LAH. The LAH groups underwent quarter laser zona thinning-assisted hatching before vitrification $(4,6$, and 8 minutes or 4,7 , and 10 minutes, respectively). After incubation, double-immunofluorescence staining was performed.

Results: The hatched blastocyst rate 72 hours after the 2-cell embryos were thawed was significantly higher in the 2LAH-ES8 group (33.3\%) than in the other groups $(p<0.05)$. In the control-8 group (22.1 \pm 4.6$)$, the cell number of the inner cell mass was higher than in the LAH groups $(p<0.05)$. The number of trophectoderm cells was higher in the 2LAH-ES6 group $(92.8 \pm 8.9)$ than in the others $(p<0.05)$. The hatched blastocyst rate 48 hours after the 8-cell embryos were thawed was higher in the 8LAH-ES4 group (45.5\%) than in the other groups, but not signifcantly. The inner cell mass cell number was highest in the 8LAH-ES7 group $(19.5 \pm 5.1, p<0.05)$. The number of trophectoderm cells was higher in the 8LAH-ES10 group $(73.2 \pm 12.1)$ than in the other groups, but without statistical significance.

Conclusion: When LAH was performed, 2-cell embryos with large blastomeres had a lower hatched blastocyst rate when the exposure to vitrification solution was shorter. Conversely, 8-cell embryos with small blastomere had a higher hatched blastocyst rate when the exposure to vitrification solution was shorter.

Keywords: Blastulation; Laser assisted hatching; Mouse embryo; Vitrification

\section{Introduction}

Rapid progress in assisted reproductive technology has resulted in the increased production of good-quality embryos from good-quality oocytes. As more embryos are produced than are used for embryo transfer in fresh cycles, the need emerged for the cryopreservation of

Received: Jul 13, 2017· Revised: Sep 3, 2017 · Accepted: Oct 18, 2017

Corresponding author: Hye Jin Kim

Department of Obstetrics and Gynecology, Chungnam National University Hospital, 282 Munhwa-ro, Jung-gu, Daejeon 35015, Korea

Tel: +82-42-280-7219 Fax: +82-42-280-7669 E-mail: good79ok@naver.com

This is an Open Access article distributed under the terms of the Creative Commons Attribution Non-Commercial License (http://creativecommons.org/licenses/by-nc/4.0/) which permits unrestricted non-commercial use, distribution, and reproduction in any medium, provided the original work is properly cited. gametes and surplus embryos. Frozen-thawed embryo transfer is now a mandatory technology that can be used to give another chance to conceive to patients in whom fresh embryo transfer was unsuccessful [1,2].

Recently, the movement towards transferring fewer embryos has resulted in greater numbers of surplus embryos, leading to a greater likelihood of having embryos cryopreserved [3]. Other applications of cryopreservation include cases where severe ovarian hyperstimulation syndrome is anticipated, various situations where fertilization is not possible on the day of oocyte retrieval, a discrepancy between the oocyte donor's oocyte retrieval period and the recipient's embryo transfer period; and cryopreservation of gametes and embryos for fertility preservation in cancer patients scheduled to receive cytotoxic 
chemotherapy or radiotherapy. These applications are gaining more ground in the field of reproductive endocrinology [4-7]. Researchers are seeking better gamete/embryo cryopreservation techniques to improve the implantation and pregnancy rates [8].

The foremost issue is the damage to the blastomere during the freezing and thawing process. Blastomere damage may cause defective cellular development, reduced blastocyst formation and development rates, and eventual adverse effects on implantation and pregnancy [9].

The vitrification technique uses high concentrations of cryoprotectants $(\mathrm{CP})$ together with a rapid temperature drop. This technique can reduce ice crystal formation by increasing the viscosity. It has become more important to improve the efficacy of the cryopreservation process, $\mathrm{CP}$, and storage container stability [10-13]. The duration of exposure of the cells to the $\mathrm{CP}$ and the concentration of the $\mathrm{CP}$ are very important factors to consider in preventing ice crystal formation and reducing toxic damage from exposure.

The embryo must escape the zona pellucida (hatching), and this is a mandatory step in implantation. Incomplete hatching leads to implantation failure and failure to conceive. In fresh embryos, an inappropriate in vitro culture system may cause hardening of the zona pellucida (zona hardening), and the hatching process may be hindered. This phenomenon is also observed in cryopreserved embryos. Appropriately and timely performed assisted hatching increases the embryo development rate, hatching rate, implantation rate, and pregnancy rate.

Therefore, in this study, the authors investigated the effect of laserassisted hatching (LAH) and different exposure times to the CP during vitrification on the embryo development rate and cellular development. Cellular development was evaluated by assessing the cell count in the inner cell mass (ICM) and trophectoderm (TE) by doublefluorescence staining.

\section{Methods}

\section{Preparation of embryos \\ 1) International Cancer Research mice}

International Cancer Research strain mice aged 4-5 weeks (females) and 9-12 weeks (males) were housed with a 12-hour light/ dark photoperiod in an environment with a controlled temperature $\left(24^{\circ} \mathrm{C}\right)$ and constant humidity. No restrictions were placed on diet and water supply.

\section{2) Recovery and culture of 2-cell and 8-cell embryos}

Intraperitoneal injections of 7.5 IU of pregnant mare's serum gonadotropin (Merck, Darmstadt, Germany) and 5 IU of human chorionic gonadotropin (Merck) were performed 48 hours apart. Female mice were sacrificed $44-68$ hours after mating by cervical dislocation, and their oviducts were removed. The oviducts were flushed with a solution containing Ham's F-10 (11-090-1K, Gibco; Life Technologies, New York, NY, USA) and 10\% serum substitute supplement (Irvine Scientific, Santa Ana, CA, USA) to recover 2-cell stage embryos.

\section{Laser-assisted hatching \\ 1) Media}

The preincubation process was performed as follows. In the center of a 60-mm culture dish (3002, Falcon; Corning Life Sciences, Tewksbury, MA, USA), each embryo was placed in a 50- $\mu \mathrm{L}$ drop of cleavage medium (CM; COOK, Queensland, Australia) under mineral oil, and put into a $6 \% \mathrm{CO}_{2}$ incubator over 6 hours at $37^{\circ} \mathrm{C}$ to equilibrate.

\section{2) Quarter laser zona thinning-assisted hatching}

An RI Saturn 5 active laser system (6-47-500; Research Instruments, Falmouth, UK) attached to an inverted microscope $(\times 40$, TMD, TE2000U; Nikon, Tokyo, Japan) and a display monitor (B19940; Samsung, Suwon, Korea) was used for quarter laser zona thinning-assisted hatching (qLZT-AH). The 60-mm culture dish was placed onto the heated $\left(37^{\circ} \mathrm{C}\right)$ displacement stage on the inverted microscope, after placing 5-10 embryos in the 2-cell and 8-cell stage in a 50- $\mu \mathrm{L}$ drop of CM. A virtual curved line was drawn following the outer contour of the zona pellucida on the display monitor, and a continuous laser beam was emitted tracing the line to drill a hole in about one fourth of the zona pellucida surface. To reduce damage to the blastomere, the laser was emitted at a point where the blastomeres were far apart, and the zona pellucida thickness was reduced by approximately $70 \%-80 \%$ between the center of the zona pellucida and the outer line. The size of the laser holes on the zona pellucida was $5-10 \mu \mathrm{m}$, and 10-15 emissions was required to drill a hole in about one fourth of the surface. The thickness and the number of laser emissions were adjusted for each embryo.

\section{Vitrification and thawing}

\section{1) Preparation of solutions and straw}

Vitrification was performed using a two-step method. Dulbecco's phosphate-buffered saline supplemented with $10 \%$ serum substitute supplement was used as a basic medium. The equilibrium solution (ES) used for step 1 was composed of basic medium, 7.5\% ethylene glycol (EG; Reagent Plus, $\geq 99 \%$, 102466; Sigma, St. Louis, MO, USA) and 7.5\% dimethyl sulfoxide (DMSO; D-2650, Sigma). For the vitrification solution used in step 2, 15.0\% EG, 15.0\% DMSO, and 0.5 $\mathrm{M}$ sucrose (S1888, Sigma) was added to the basic medium. A thawing solution mixed with $1.0 \mathrm{M}$ sucrose (thawing solution 1,TS 1) and $0.5 \mathrm{M}$ sucrose (thawing solution 2, TS 2) were used.

We used a closed-pulled straw (CPS), modified as described by Chen et al. [8], for murine embryo vitrification. The $0.25-\mu \mathrm{L}$ plastic straws 
were heat-softened over an alcohol lamp for 2-3 seconds and pulled manually. The pulled straws were cut at the tapered end with a surgical scalpel. The end of the straw was sealed using heated forceps.

\section{2) Vitrification}

All vitrification procedures were performed at room temperature $\left(24^{\circ} \mathrm{C}-26^{\circ} \mathrm{C}\right)$. The murine 2-cell embryos were transferred to the ES solution and treated for 4, 6, or 8, minutes, and the 8-cell embryos were transferred to ES solution and treated for 4,7 , or 10 minutes. After transfer to the vitrification solution, fewer than five embryos were loaded per CPS. The process was performed rapidly, with less than 1-minute elapsing from being in the vitrification solution to being submerged in liquid nitrogen. The CPSs were thawed after 2 weeks of cryopreservation.

\section{3) Observations after thawing}

After the straws were removed from liquid nitrogen to room air conditions, they were warmed by hand grasping. Embryos were recovered after removing the straw cap. Embryos were placed into the well containing TS 1 solution for 1 minute at $37^{\circ} \mathrm{C}$, followed by the TS 2 solution for 3 minutes and the base medium for 5 minutes. After placing 5-10 embryos in a 50- $\mu \mathrm{L}$ drop of CM (equilibrated for 14-18 hours in a $\mathrm{CO}_{2}$ incubator $\left.\left[37^{\circ} \mathrm{C}, 6 \%\right]\right)$, the embryos were incubated for 72 hours (2-cell embryos) or 48 hours (8-cell embryos) in blastocyst medium (COOK). Embryos were monitored every 24 hours for survival and hatching rate. Blastocysts that fully hatched or hatched out of the zona pellucida were considered to have hatched. Every experiment was performed 8 times.

\section{Double-fluorescence staining of blastocysts}

For TE cell staining, solution 1 was prepared by mixing $100 \mu \mathrm{g} / \mathrm{mL}$ of propidium iodide (P-4170, Sigma) and 1\% Triton X-100 (T-93443, Sigma) in Ham's F-10 solution. Solution 2 was a mixture of $25 \mu \mathrm{g}$ of bisbenzimide (B-2261, Sigma) in 99.9\% ethanol, which was prepared to stain the ICM. In order to carry out double-fluorescence staining, the blastocysts were stained in solution 1 for 10 seconds and transferred to solution 2 for 2 hours or more at $4^{\circ} \mathrm{C}$. The stained blastocysts were washed with glycerol (G2025, Sigma) and put onto a slide glass for observation under a fluorescence microscope.

\section{Statistical analysis}

The blastocyst formation rate is reported as percentage values. The standard deviations of discrete variables between groups were compared using SPSS ver. 18.0 (SPSS Inc., Chicago, IL, USA). Differences in the blastocyst cell number between two selected groups were analyzed by the Student $t$-test. A value of $p<0.05$ was considered to indicate statistical significance.

\section{Results}

\section{Effects of LAH and exposure time to vitrification solution on blastocyst formation in mouse 2-cell embryos}

To investigate the best exposure time to ES, mouse 2-cell embryos were vitrified with ES exposures of 4, 6, or 8 minutes after qLZT-AH (Figure 1). The survival rate, 24-hour morula formation rate, and 48/72-hour hatching/hatched blastocyst formation rate after thawing are shown in Table 1. The survival rate was higher in the $2 \mathrm{LAH}-\mathrm{ES} 4$ group ( $\mathrm{LAH}+4$ minutes of ES exposure, 92.4\%) than in the other groups, but the difference was not statistically significant. The 24hour morula formation rate was significantly higher in the $2 \mathrm{LAH}-\mathrm{ES} 8$ group ( $\mathrm{LAH}+8$ minutes of $\mathrm{ES}$ exposure, 58.8\%) than in the other groups. The 48-hour blastocyst formation rate was highest in the
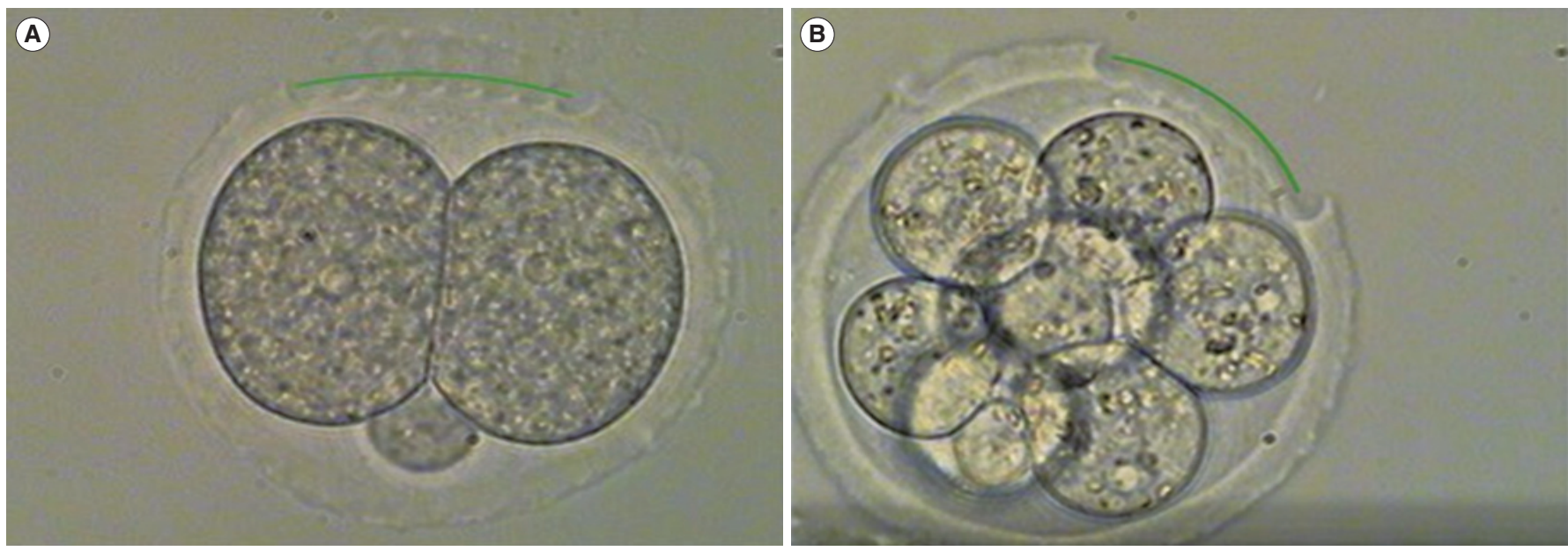

Figure 1. Photographs of quarter laser zona thinning-assisted hatching. Twenty-five percent of the zona pellucida of a 2-cell and 8-cell fresh embryo is thinned to a depth of 70\%-80\% (×400). (A) Two-cell embryo before vitrification, (B) 8-cell embryo before vitrification. 
Table 1. Effects of laser-assisted hatching and exposure time to vitrification solution on blastocyst formation in mouse 2-cell embryos

\begin{tabular}{|c|c|c|c|c|c|c|c|c|}
\hline \multirow[b]{3}{*}{ Group } & \multirow{3}{*}{$\begin{array}{l}\text { No. of } \\
\text { thawing } \\
\text { embryos } \\
\text { (2-cell) }\end{array}$} & \multicolumn{7}{|c|}{ No. of embryos developed } \\
\hline & & \multicolumn{3}{|c|}{ at $48 \mathrm{hr}$} & \multicolumn{4}{|c|}{ at $72 \mathrm{hr}$} \\
\hline & & Morula & Blastocyst ${ }^{a)}$ & $\begin{array}{l}\text { Hatching } \\
\text { blastocyst }\end{array}$ & Blastocyst & $\begin{array}{l}\text { Hatching } \\
\text { blastocyst }^{\text {a) }}\end{array}$ & $\begin{array}{l}\text { Hatched } \\
\text { blastocyst }\end{array}$ & $\begin{array}{c}\text { Hatching + } \\
\text { hatched } \\
\text { blastocyst }\end{array}$ \\
\hline Control-8 & 58 & $21(36.2 \pm 25.9)^{b c}$ & $31(53.5 \pm 16.1)$ & $2(3.5 \pm 6.8)^{b}$ & $19(32.8 \pm 13.2)^{\mathrm{a}}$ & $24(41.4 \pm 15.6)$ & $9(15.5 \pm 9.6)^{b}$ & $33(56.9 \pm 14.8)^{b}$ \\
\hline 2LAH-ES8 & 51 & $30(58.8 \pm 22.9)^{\mathrm{a}}$ & $27(52.9 \pm 8.4)$ & $4(7.8 \pm 8.3)^{\mathrm{cb}}$ & $9(15.5 \pm 14.7)^{\mathrm{ab}}$ & $21(41.2 \pm 16.9)$ & $17(33.3 \pm 13.3)^{\mathrm{a}}$ & $38(74.5 \pm 14.4)^{\mathrm{a}}$ \\
\hline 2LAH-ES6 & 62 & $30(48.4 \pm 29.0)^{\mathrm{cb}}$ & $25(40.3 \pm 32.6)$ & $11(17.7 \pm 20.5)^{\mathrm{a}}$ & $4(6.5 \pm 7.1)^{b}$ & $33(53.2 \pm 21.1)$ & $12(19.4 \pm 11.6)^{\mathrm{ab}}$ & $4(72.6 \pm 20.8)^{\mathrm{ab}}$ \\
\hline 2LAH-ES4 & 52 & $13(25.0 \pm 16.1)^{c}$ & $19(36.5 \pm 21.9)$ & $4(7.7 \pm 10.9)^{\mathrm{ab}}$ & $10(19.2 \pm 27.2)^{\mathrm{ab}}$ & $23(44.2 \pm 19.8)$ & $10(19.2 \pm 19.6)^{\mathrm{ab}}$ & $33(63.5 \pm 27.7)^{\mathrm{ab}}$ \\
\hline
\end{tabular}

Values are presented as number (\%, mean \pm standard deviation).

Control-8, 8 minutes of vitrification without quarter laser zona thinning-assisted hatching; $2 \mathrm{LAH-ES8,} 8$ minutes of vitrification after quarter laser zona thinningassisted hatching; 2LAH-ES6, 6 minutes of vitrification after quarter laser zona thinning-assisted hatching; 2LAH-ES4, 4 minutes of vitrification after quarter laser zona thinning-assisted hatching.

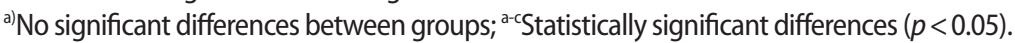

Table 2. Effects of laser-assisted hatching and exposure time to vitrification solution on blastocyst formation in mouse 8-cell embryos

\begin{tabular}{|c|c|c|c|c|c|c|c|c|}
\hline \multirow{3}{*}{ Group } & \multirow{3}{*}{$\begin{array}{c}\text { No. of } \\
\text { thawing } \\
\text { embryos } \\
\text { (8-cell) }\end{array}$} & \multicolumn{7}{|c|}{ No. of embryos developed } \\
\hline & & \multicolumn{3}{|c|}{ at $24 \mathrm{hr}$} & \multicolumn{4}{|c|}{ at $48 \mathrm{hr}$} \\
\hline & & Morula & Blastocyst & $\begin{array}{l}\text { Hatching } \\
\text { blastocyst }^{\text {a) }}\end{array}$ & Blastocyst & $\begin{array}{l}\text { Hatching } \\
\text { blastocyst }\end{array}$ & $\begin{array}{c}\text { Hatched } \\
\text { blastocyst }{ }^{\mathrm{a})}\end{array}$ & $\begin{array}{l}\text { Hatching + } \\
\text { hatched } \\
\text { blastocyst }\end{array}$ \\
\hline Control-10 & 54 & $26(48.2 \pm 20.1)^{\mathrm{a}}$ & $27(50.0 \pm 18.3)^{b}$ & $1(1.9 \pm 4.4)$ & $8(14.8 \pm 13.9)^{a}$ & $27(50.0 \pm 25.7)$ & $19(35.2 \pm 20.6)$ & $46(85.2 \pm 13.9)^{b}$ \\
\hline 8LAH-ES10 & 46 & $19(41.3 \pm 37.2)^{a b}$ & $25(54.4 \pm 35.2)^{\mathrm{ab}}$ & $2(4.4 \pm 9.5)$ & $2(4.4 \pm 9.3)^{\mathrm{ab}}$ & $29(63.0 \pm 40.7)$ & $15(32.6 \pm 22.2)$ & $44(95.7 \pm 36.6)^{a}$ \\
\hline 8LAH-ES7 & 58 & $32(55.2 \pm 31.6)^{\mathrm{a}}$ & $24(41.4 \pm 30.6)^{b}$ & $2(3.5 \pm 8.8)$ & $2(3.5 \pm 14.1)^{a}$ & $35(60.4 \pm 25.3)$ & $20(34.5 \pm 18.7)$ & $55(94.8 \pm 14.1)^{\mathrm{ab}}$ \\
\hline 8LAH-ES4 & 66 & $20(30.3 \pm 17.5)$ & $46(69.7 \pm 17.5)^{\mathrm{a}}$ & $0(0.0 \pm 0.0)$ & $0(0.0 \pm 0.0)^{b}$ & $35(53.0 \pm 18.0)$ & $30(45.5 \pm 23.4)$ & $65(98.5 \pm 8.8)^{a}$ \\
\hline
\end{tabular}

Values are presented as number (\%, mean \pm standard deviation).

Control-10, 10 minutes of vitrification without quarter laser zona thinning-assisted hatching; 8LAH-ES10, 10 minutes of vitrification after quarter laser zona thinning-assisted hatching; 8LAH-ES7, 7 minutes of vitrification after quarter laser zona thinning-assisted hatching; 8LAH-ES4, 4 minutes of vitrification after quarter laser zona thinning-assisted hatching.

a) No significant differences between groups; ${ }^{\text {a,b }}$ Statistically significant difference $(p<0.05)$.

2LAH-ES6 group (LAH+6 minutes of ES exposure, $53.2 \%$ ), but this trend was not statistically significant. The hatched blastocyst formation rate was highest in the 2LAH-ES8 group (33.3\%).

\section{Effects of LAH and exposure time to vitrification solution on blastocyst formation in mouse 8-cell embryos}

To investigate the best exposure time to ES, mouse 8-cell embryos were vitrified with $\mathrm{ES}$ exposures of 4, 7, or 10 minutes after qLZT-AH (Figure 1). The 24-hour blastocyst formation rate and 48-hour hatching/hatched blastocyst formation rate after thawing are shown in Table 2. The 24-hour blastocyst formation rate was significantly higher in the 8LAH-ES4 group (LAH+4 minutes of ES exposure, 69.7\%) than in the other groups. The 48-hour hatching blastocyst formation rate was higher in the 8LAH-ES10 group ( $\mathrm{LAH}+10$ minutes of ES exposure, 63.0\%) than the others, and the 48-hour hatched blastocyst formation rate was highest in the 8LAH-ES4 group (45.5\%), but these trends were not statistically significant.

\section{Effects of LAH and the exposure time to vitrification solution on cell numbers in mouse 2-cell embryos}

Mouse 2-cell embryos were vitrified with ES exposures of 4, 6, or 8 minutes after qLZT-AH. The cell counts of the ICM and TE of the blastocysts determined by double-fluorescence staining 72 hours after thawing are shown in Figure 2 and Table 3. The blastocyst ICM cell count was highest in the control-8 group (22.1 \pm 4.6$)$, and the TE cell count and total cell count were highest in the 2LAH-ES6 group ( $92.8 \pm 8.9$ and $109.0 \pm 8.4$, respectively). The proportion of the ICM cell count relative to the total cell count was highest in the control-8 group $(23.4 \% \pm 4.6 \%)$.

\section{Effects of LAH and exposure time to vitrification solution on cell numbers in mouse 8-cell embryos}

Mouse 8-cell embryos were vitrified with ES exposures of 4, 7, or 10 minutes after qLZT-AH. The cell counts of the ICM and TE of the blastocysts determined by double-fluorescence staining 48 hours after thawing are shown in Figure 2 and Table 4. The blastocyst ICM cell 

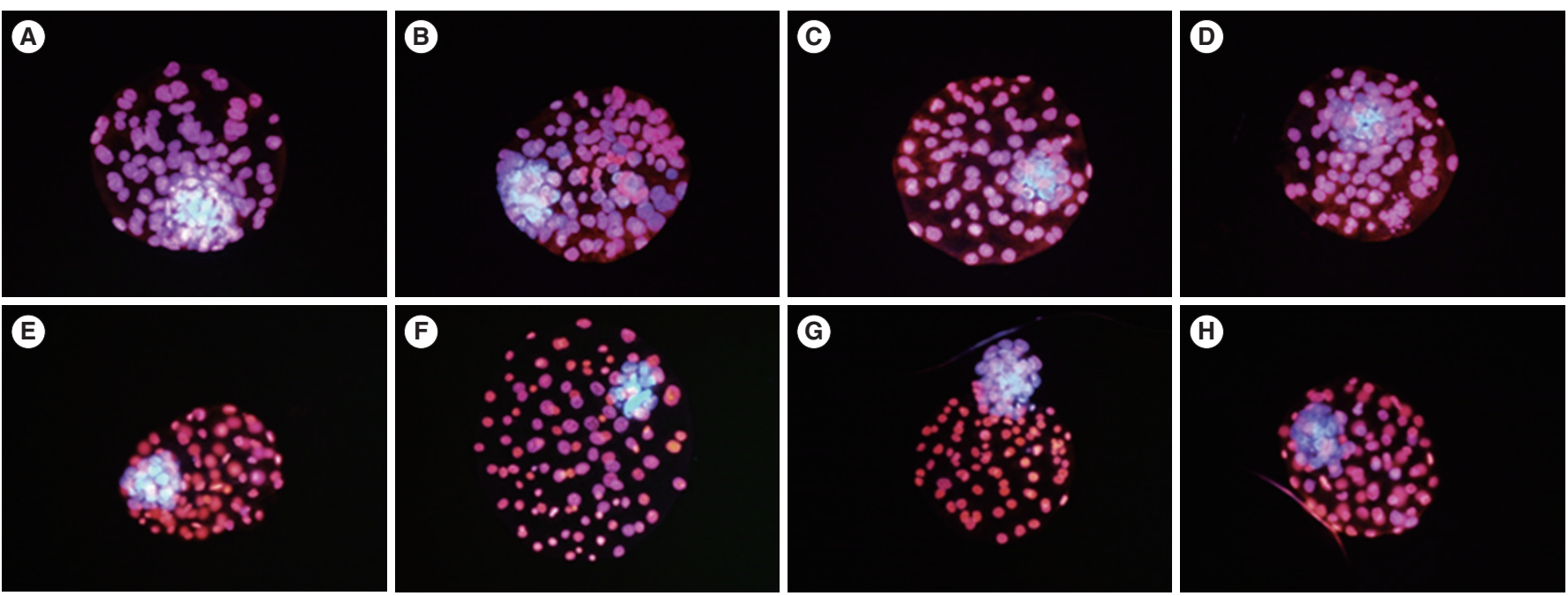

Figure 2. Photograph of cells differentially stained in a mouse hatched blastocyst $(\times 400$, double-fluorescence staining; inner cell mass, blue; trophectoderm, pink). (A-D) Two-cell mouse embryo, (E-H) 8-cell mouse embryo. (A) Control-8, 8 minutes of vitrification without quarter laser zona thinning-assisted hatching (qLZT-AH), 72 hours after thawing. (B) 2LAH-ES8, 8 minutes of vitrification after qLZT-AH, 72 hours after thawing. (C) 2LAH-ES6, 6 minutes of vitrification after qLZT-AH, 72 hours after thawing. (D) 2LAH-ES4, 4 minutes of vitrification after qLZT-AH, 72 hours after thawing. (E) Control-10, 10 minutes of vitrification without qLZT-AH, 48 hours after thawing. (F) 8LAH-ES10, 10 minutes of vitrification after qLZT-AH, 48 hours after thawing. (G) 8LAH-ES7, 7 minutes of vitrification after qLZT-AH, 48 hours after thawing. (H) 8LAH-ES4, 4 minutes of vitrification after qLZT-AH, 48 hours after thawing.

Table 3. Effects of laser-assisted hatching and exposure time to vitrification solution on cell number in mouse 2-cell embryos

\begin{tabular}{lcccrc}
\hline Group & \multirow{2}{*}{$\begin{array}{c}\text { No. of dyed } \\
\text { embryos }\end{array}$} & ICM & TE & Total & $\begin{array}{c}\text { \% ICM } \\
\text { (mean } \pm \text { SD) }\end{array}$ \\
\cline { 3 - 6 } & 7 & $22.1^{\mathrm{a}}$ & $72.3^{\mathrm{b}}$ & 94.4 & $23.4 \pm 4.6$ \\
Control-8 & 7 & $17.5^{\mathrm{ab}}$ & $76.8^{\mathrm{b}}$ & 94.3 & $18.6 \pm 8.5$ \\
2LAH-ES8 & 6 & $16.0^{\mathrm{b}}$ & $92.8^{\mathrm{a}}$ & 109.0 & $14.7 \pm 2.9$ \\
2LAH-ES6 & 5 & $16.4^{\mathrm{b}}$ & $79.0^{\mathrm{b}}$ & 95.3 & $17.2 \pm 3.4$ \\
2LAH-ES4 & 9 & &
\end{tabular}

ICM, inner cell mass; TE, trophectoderm; SD, standard deviation; Control-8, 8 minutes of vitrification without quarter laser zona thinning-assisted hatching; 2LAH-ES8, 8 minutes of vitrification after quarter laser zona thinning-assisted hatching; 2LAH-ES6, 6 minutes of vitrification after quarter laser zona thinning-assisted hatching; 2LAH-ES4, 4 minutes of vitrification after quarter laser zona thinning-assisted hatching.

a,bStatistically significant difference $(p<0.05)$.

count was highest in the 8LAH-ES7 group ( $\mathrm{LAH}+7$ minutes of ES exposure, 19.5 \pm 5.1$)$, and the TE cell count and total cell count were highest in the 8LAH-ES10 group $(73.2 \pm 12.1$ and $88.8 \pm 12.1$, respectively), but these trends were not statistically significant. The proportion of the ICM cell count relative to the total cell count was highest in the $8 \mathrm{LAH}-\mathrm{ES} 7$ group $(22.5 \% \pm 4.3 \%)$.

\section{Discussion}

$\mathrm{CP}$ are mandatory for cell cryopreservation. However, the chemical
Table 4. Effects of laser-assisted hatching and exposure time to vitrification solution on cell number in mouse 8-cell embryos

\begin{tabular}{|c|c|c|c|c|c|}
\hline \multirow[b]{2}{*}{ Group } & \multirow[b]{2}{*}{$\begin{array}{l}\text { No. of dyed } \\
\text { embryos }\end{array}$} & \multicolumn{4}{|c|}{ No. of cells } \\
\hline & & ICM & $T E^{a)}$ & Total & $\begin{array}{c}\% \text { ICM } \\
(\text { mean } \pm \text { SD) }\end{array}$ \\
\hline Control-10 & 8 & $18.1^{\mathrm{a}}$ & 68.0 & 86.1 & $21.0 \pm 3.8$ \\
\hline 8LAH-ES10 & 6 & $14.0^{b}$ & 73.2 & 88.8 & $15.8 \pm 4.2$ \\
\hline 8LAH-ES7 & 12 & $19.5^{\mathrm{a}}$ & 67.3 & 86.8 & $22.5 \pm 4.3$ \\
\hline 8LAH-ES4 & 6 & $14.0^{b}$ & 67.7 & 81.7 & $17.1 \pm 5.9$ \\
\hline
\end{tabular}

ICM, inner cell mass; TE, trophectoderm; SD, standard deviation; Control-10, 10 minutes of vitrification without quarter laser zona thinning-assisted hatching; 8LAH-ES10, 10 minutes of vitrification after quarter laser zona thinning-assisted hatching; 8LAH-ES7, 7 minutes of vitrification after quarter laser zona thinning-assisted hatching; 8LAH-ES4, 4 minutes of vitrification after quarter laser zona thinning-assisted hatching.

${ }^{a}$ No significant differences between groups $(p<0.05)$; ${ }^{\text {a,b }}$ Statistically significant difference.

toxicity of CP and ice crystallization from inappropriate freezing methods diminishes the survival rate and embryo development rate after thawing. Therefore, the type and concentration of the CP, as well as exposure time to the $\mathrm{CP}$ and surrounding environment (e.g., temperature) should be selected with caution [14-17].

In previous studies, embryos vitrified at the pronuclear stage showed a higher embryo development rate than those vitrified at the cleavage stage [18]. The implantation rates of mouse embryos were $27.7 \%$ (4-cell embryos) and 34.6\% (7-to 8-cell embryos) [18]. This is because the more advanced the embryo stage, the more likely 
it is to continue the development process [18]. The survival rate of human cleavage-stage embryos following 3 days of vitrification was higher in the late-cleavage stage embryos, with survival rates of 21.1\% (6-cell), 39.7\% (6- to 7-cell), and 79.2\% (8-cell) [19]. In our study, we compared mouse 2-cell embryos and 8-cell embryos; the survival rate ( $91.4 \%$ and $100 \%$, respectively), the hatching blastocyst rate $(41.4 \%$ and $50.0 \%$, respectively), and the hatched blastocyst rate (15.5\% and $35.2 \%$, respectively); all showed superior results in the late-cleavage stage embryos, similar to previous studies.

The optimal temperature and exposure time to ES during vitrification were found to be $20^{\circ} \mathrm{C}$ and 30 seconds, and the implantation rate and live birth rate were $70.4 \%$ and $55.2 \%$, respectively [17]. In human 3-day vitrification, the implantation rate and live birth rate were higher in the 9- to 10-minute exposure group than in the 5- to 6-minute, 7- to 8-minute, or 11- to 12-minute exposure groups. Ten minutes of exposure was most effective for cleavage-stage embryos [20]. In the current study, when we divided 2-cell and 8-cell embryos into 4-, 6-, and 8-minute groups and 4-, 7-, and 10-minute groups, respectively, a shorter exposure to the ES resulted in a lower blastocyst formation rate in the 2-cell embryos $(19.2 \%, 19.4 \%$, and $33.3 \%$, respectively; Table 1), but a higher blastocyst formation rate in the 8-cell embryos (45.5\%, 34.5\%, and 32.6\%, respectively; Table 2).

A time-lapse study of mouse embryo volume in response to exposure to five different $\mathrm{CP}$ (EG, DMSO, propylene glycol, acetamide, and glycerol) showed a $90 \%-110 \%$ recovery rate for oocytes exposed for 10 minutes, as well as a $65 \%-95 \%$ recovery rate in 2-cell embryos and a $65 \%-110 \%$ recovery rate in 8 -cell embryos when exposed for 5 minutes. In blastocysts, longer exposure to acetamide and PG reduced the recovery rate, and the authors concluded that the exposure time to CP can be reduced as embryos develop [16]. Mouse pronuclear embryos exposed to $15 \%$ EG and 15\% DMSO for either 10 minutes or 20 minutes showed no difference in the survival rate (100\% vs. $100 \%$ ), but the hatched blastocyst formation rate was lower (23\% vs. 0\%) [14]. In the current study, assisted hatching was performed in mouse 2-cell and 8-cell embryos and the vitrification/ warming process used EG and DMSO. The blastocyst formation rate was $21.5 \%$ (2-cell) and $37.5 \%$ (8-cell).

The impaired embryo development following cryopreservation can be explained by faulty intracellular $\mathrm{pH}$ regulation, metabolism errors, and a collapse in energy production due to the damage to the $\mathrm{Na}^{+} /$ $\mathrm{H}^{+}$antiporter and $\mathrm{HCO}_{3}{ }^{-} / \mathrm{Cl}^{-}$exchanger [21]. Intracellular $\mathrm{pH}$ regulation is the reason why 8-cell embryos have a higher embryo development rate than 2-cell embryos [22,23], and intracellular pH is important for regulating metabolism, energy production, and cleavage [24].

The zona pellucida of mammalian oocytes includes a large amount of hyaluronic acid, which acts as a protective protein-hydrogel barri- er. Metaphase II oocytes deprived of the zona pellucida using 15\% $\mathrm{PrOH}$ and $1.4 \mathrm{M}$ trehalose showed a markedly reduced survival rate after vitrification (92\% and $13 \%)$. The presence of the zona pellucida has a great impact on oocyte survival [25]. In fresh embryo transfer cycles, assisted hatching is usually performed on 3-day incubated cleavage-stage embryos. The purpose of this delay is to reduce excessive exposure to the extracellular environment by a repeated embryo selection process, and to perform assisted hatching only in good-quality embryos selected by observing the embryo development rate before embryo transfer. However, there is a paucity of studies on the optimal timing of assisted hatching to overcome zona hardening during the freezing-thawing process and to promote the embryo development rate.

LAH showed a higher implantation rate than controls among women who experienced implantation failure more than twice (10.9\% vs. 2.6\%) [26]. Among five different AH methods in mouse 2-cell embryos, the hatched blastocyst rate was highest when one fourth of the zona pellucida was removed using LAH [27]. A high hatching rate in mouse blastocysts (97\%) was reported when artificial shrinkage and assisted hatching were performed before vitrification. Assisted hatching was effective in promoting the hatching rate after the cryopreservation of blastocysts [28]. Artificial shrinkage in mouse blastocysts combined with assisted hatching before cryopreservation was associated with a higher hatched blastocyst formation rate than observed for mechanical AH [29].

Based on these findings, we performed LAH of one fourth of the zona pellucida in mouse 2-cell and 8-cell embryos. The control group was exposed to CP for 8 or 10 minutes without LAH [14,30], and the study group was divided into subgroups with 4,6 , or 8 minutes or 4 , 7 , or 10 minutes of exposure. The embryo survival rate, blastocyst formation rate, hatching/hatched blastocyst rate, and cell count were assessed.

The recovery rate and survival rate have been found to vary depending on the straw used for vitrification. The CPS method showed an improved embryo survival rate compared to conventional straws $[31,32]$. The previously reported blastocyst survival rate was 391 of 414 (94.4\%), and we achieved similar survival rates using the CPS method in our study (430/447, 96.2\%).

We used the double-fluorescence staining method reported by Park et al. [33], and only used fully hatched embryos with clearly distinguishable cellular structures. In a previous study, mouse 2-cell embryos after 72 hours of incubation showed similar ICM, TE, and total cell counts in the LAH group and controls (ICM, 19.4 \pm 4.7 vs. $21.0 \pm$ 2.0; TE, $55.0 \pm 19.5$ vs. $55.0 \pm 4.0$; total, $74.3 \pm 17.8$ vs. $75.3 \pm 3.0)[27,34]$. In the current study, the TE and total cell counts were significantly different between the LAH group and the controls, but similar ICM cell counts were found. 
Rapid embryo development has been associated with a higher cell count and a higher proportion of the ICM [35]. In our study, the hatched blastocyst rate was highest (17.7\%) when LAH was performed on 2-cell embryos and the duration of CP exposure was 6 minutes (the 2LAH-ES6 group). The TE cell and total cell counts were also highest in this group, similarly to a previous study [35]. However, the ICM cell count was the lowest in this group, similarly to the study by Park et al. [27].

There was a nonsignificant difference in the 24-hour hatching blastocyst rate $(4.4 \%)$, TE cell count $(73.2+12.1)$, and total cell count $(88.8 \pm 12.1)$ in the 8LAH-ES10 group (8-cell embryos). Mouse 8-cell embryos showed a reduced blastocyst cell count $(39.4 \pm 13.1$ and $57.4 \pm 23.8)$ after cryopreservation compared to controls $(69.3 \pm 17.4)$ [36]. In a study of blastocysts and expanded blastocysts cultured from mouse 4-cell embryos, different exposure times to $C P(4,8$, and 15 minutes) were applied during vitrification. The survival rates of expanded blastocysts were $91.6 \%$ (4 minutes), 100\% (8 minutes), and $93.7 \%$ (15 minutes), and the optimal exposure time was 8 minutes. The cell counts of the blastocysts and expanded blastocysts were also superior in the 8-minute exposure group (8-minute group, 44.1 vs. 59.6; control, 32.0 vs. 46.3; 4-minute group, 38.7 vs. 46.4, respectively) [37].

In the current study, LAH combined with reducing exposure to the $\mathrm{CP}$ adversely affected the embryo development rate in 2-cell embryos, in which the blastomeres are larger. In 8-cell embryos in which the blastomeres are smaller, shorter exposure to CP improved both the embryo development rate and the hatched blastocyst formation rate. While different exposure times to $\mathrm{CP}$ had no impact on cell counts, LAH was associated with a difference in the ICM cell count, but not in the total cell count.

Based on these results, we have confirmed that LAH may allow the exposure time to $\mathrm{CP}$ to be reduced. Further studies are needed to elucidate the effects of LAH in different embryo stages and the effects of different CP on the cell count.

\section{Conflict of interest}

No potential conflict of interest relevant to this article was reported.

\section{References}

1. Bergh C, Werner C, Nilsson L, Hamberger L. Cumulative birth rates following cryopreservation of all embryos in stimulated in vitro fertilization (IVF) cycles. J Assist Reprod Genet 1995;12:1914.

2. Trounson A. Preservation of human eggs and embryos. Fertil Steril 1986;46:1-12.
3. Vanderzwalmen P, Delval A, Chatziparasidou A, Bertin G, Ectors F, Lejeune $B$, et al. Pregnancies after vitrification of human day 5 embryos. Hum Reprod 1997;12(Suppl):98.

4. Kahn JA, von During V, Sunde A, Sordal T, Molne K. The efficacy and efficiency of an in-vitro fertilization programme including embryo cryopreservation: a cohort study. Hum Reprod 1993; 8:247-52.

5. Van Voorhis BJ, Syrop CH, Allen BD, Sparks AE, Stovall DW. The efficacy and cost effectiveness of embryo cryopreservation compared with other assisted reproductive techniques. Fertil Steril 1995;64:647-50.

6. D'Angelo A, Amso NN. Embryo freezing for preventing ovarian hyperstimulation syndrome: a Cochrane review. Hum Reprod 2002;17:2787-94.

7. Liebermann J, Tucker MJ. Comparison of vitrification and conventional cryopreservation of day 5 and day 6 blastocysts during clinical application. Fertil Steril 2006;86:20-6.

8. Chen SU, Lien YR, Chao Kh, Lu HF, Ho HN, Yang YS. Cryopreservation of mature human oocytes by vitrification with ethylene glycol in straws. Fertil Steril 2000;74:804-8.

9. Kolibianakis EM, Zikopoulos K, Devroey P. Implantation potential and clinical impact of cryopreservation: a review. Placenta 2003;24 Suppl B:S27-33.

10. Dhali A, Manik RS, Das SK, Singla SK, Palta P. Post-vitrification survival and in vitro maturation rate of buffalo (Bubalus bubalis) oocytes: effect of ethylene glycol concentration and exposure time. Anim Reprod Sci 2000;63:159-65.

11. Eum JH, Park JK, Lee WS, Cha KR, Yoon TK, Lee DR. Long-term liquid nitrogen vapor storage of mouse embryos cryopreserved using vitrification or slow cooling. Fertil Steril 2009;91:1928-32.

12. Magnusson V, Feitosa WB, Goissis MD, Yamada C, Tavares LM, D'Avila Assumpcao ME, et al. Bovine oocyte vitrification: effect of ethylene glycol concentrations and meiotic stages. Anim Reprod Sci 2008;106:265-73.

13. Manjunatha BM, Gupta PS, Ravindra JP, Devaraj M, Nandi S. Effect of vitrification medium composition and exposure time on post-thaw development of buffalo embryos produced in vitro. Vet J 2009;179:287-91.

14. Kim JC, Park SB, Nam YS, Seo BB, Kim JM, Song HB. The effect of cryopreservation condition on developmental rate of pronuclear stage embryos and vitrification of mouse oocytes. J Embryo Transf 2011;26:201-07.

15. Yang KC, Kang HG, Lee HC, Lee HH, Ko DS, Yang H, et al. Toxic effect of cryoprotectants on embryo development in a murine model. Korean J Fertil Steril 2004;31:59-65.

16. Pedro PB, Yokoyama E, Zhu SE, Yoshida N, Valdez DM Jr, Tanaka $M$, et al. Permeability of mouse oocytes and embryos at various 
developmental stages to five cryoprotectants. J Reprod Dev 2005;51:235-46.

17. Otsuka J, Takahashi A, Nagaoka M, Funabashi H. Optimal equilibration conditions for practical vitrification of two-cell mouse embryos. Comp Med 2002;52:342-6.

18. Dobrinsky JR, Pursel VG, Long CR, Johnson LA. Birth of piglets after transfer of embryos cryopreserved by cytoskeletal stabilization and vitrification. Biol Reprod 2000;62:564-70.

19. El-Danasouri I, Selman H. Successful pregnancies and deliveries after a simple vitrification protocol for day 3 human embryos. Fertil Steril 2001;76:400-2.

20. Xiong S, Liu JX, Gao Y, Liu WW, Wu LH, Han W, et al. Shortened equilibration time can compromise clinical outcomes in human embryo vitrification. Hum Fertil (Camb) 2016;19:114-9.

21. Lane M, Lyons EA, Bavister BD. Cryopreservation reduces the ability of hamster 2-cell embryos to regulate intracellular $\mathrm{pH}$. Hum Reprod 2000;15:389-94.

22. Lane M, Baltz JM, Bavister BD. Regulation of intracellular $\mathrm{pH}$ in hamster preimplantation embryos by the sodium hydrogen (Na+/H+) antiporter. Biol Reprod 1998;59:1483-90.

23. Leclerc $C$, Becker $D$, Buehr $M$, Warner A. Low intracellular $\mathrm{pH}$ is involved in the early embryonic death of DDK mouse eggs fertilized by alien sperm. Dev Dyn 1994;200:257-67.

24. Begg DA, Rebhun LI. pH regulates the polymerization of actin in the sea urchin egg cortex. J Cell Biol 1979;83:241-8.

25. Choi JK, Yue T, Huang H, Zhao G, Zhang M, He X. The crucial role of zona pellucida in cryopreservation of oocytes by vitrification. Cryobiology 2015;71:350-5.

26. Petersen CG, Mauri AL, Baruffi RL, Oliveira JB, Massaro FC, Elder K, et al. Implantation failures: success of assisted hatching with quarter-laser zona thinning. Reprod Biomed Online 2005;10: 224-9.

27. Park SB, Kim HJ, Choi YB, Ahn KH, Lee KH, Yang JB, et al. The effect of various assisted hatching techniques on the mouse early embryo development. Clin Exp Reprod Med 2014;41:68-74.

28. Jo DH, Ko GR, Jung JH, Choi JR, Joo JK, Lee KS. Effects of the arti- ficial shrinkage and assisted hatching before vitrification on the development of the vitrified mouse expanding blastocysts. Korean J Reprod Med 2008;35:275-83.

29. Kim HJ, Lee KH, Park SB, Choi YB, Yang JB. The effect of artificial shrinkage and assisted hatching on the development of mouse blastocysts and cell number after vitrification. Clin Exp Reprod Med 2015;42:94-100.

30. Kim JC, Seo BB, Park SB, Kim JM. The effect of various vitrification methods on developmental rate of mouse pronuclear embryos at different recovery times. J Embryo Transf 2012;27:63-9.

31. Bagis H, Mercan HO, Cetin S, Sekmen S. The effect of equilibration time on survival and development rates of mouse pronuclear-stage embryos vitrified in solid surface (SSV) and convential straws: in vitro and in vivo evaluations. Mol Reprod Dev 2005;72:494-501.

32. Isachenko V, Montag M, Isachenko E, Zaeva V, Krivokharchenko I, Shafei R, et al. Aseptic technology of vitrification of human pronuclear oocytes using open-pulled straws. Hum Reprod 2005; 20:492-6.

33. Park SB, Park KS, Lee TH, Chun SS, Kim KS, Song HB. Effects of various addition and exclusion time of glucose on development of mouse two-cell embryos. Reprod Dev Biol 2004;28:227-33.

34. Thouas GA, Korfiatis NA, French AJ, Jones GM, Trounson AO. Simplified technique for differential staining of inner cell mass and trophectoderm cells of mouse and bovine blastocysts. Reprod Biomed Online 2001;3:25-9.

35. Iwasaki S, Yoshiba N, Ushijima H, Watanabe S, Nakahara T. Morphology and proportion of inner cell mass of bovine blastocysts fertilized in vitro and in vivo. J Reprod Fertil 1990;90:279-84.

36. Trounson A, Sjoblom P. Cleavage and development of human embryos in vitro after ultrarapid freezing and thawing. Fertil Steril 1988;50:373-6.

37. Kader A, Sharma RK, Falcone T, Agarwal A. Mouse blastocyst previtrification interventions and DNA integrity. Fertil Steril 2010; 93:1518-25. 